\title{
Rib Fracture in Buffalo with Ruminal Cannula
}

\author{
Francisco Décio de Oliveira Monteiro, Gabriela Melo Alves dos Santos, Hugo Haick Perdigão, \\ Luiz Henrique Vilela Araújo, André Guimaraes Maciel e Silva, José Alcides Sarmento Silveira, \\ Marcos Dutra Duarte \& Pedro Paulo Maia Teixeira
}

\begin{abstract}
Background: Buffalos are very rustic animals that are adapted to adverse conditions, but the lack of adequate management can increase the susceptibility of these animals to several diseases. Rib fracture in this species is usually related to mineral deficiency and complications resulting from unappropriated management. Rib fractures in ruminants are rarely diagnosed and usually present conservative treatment; however, cases with presence of contaminated wounds require extra attention. The objective of this work was to report an atypical case of open fracture of the last rib in a buffalo with ruminal cannula, describing the case from diagnosis to surgical treatment.

Case: An adult female water buffalo (Bubalus bubalis) that was well fed and receiving minerals, with implantation of a ruminal cannula, presented a lesion around the ruminal cannula, with increasing volume, exudation, and myiasis. The general parameters and behavior of the animal were apparently normal. The animal presented normal appetite and respiration and good physical condition and nutritional state, with pain reaction to the touch in the region of the lesion and their adjacencies; it presented no claudication and reluctance to remain in left lateral decubitus, and no discomfort. The clinical inspection of the cutaneous lesion showed an oblique-type fracture in the body of the last left rib, with exposed bone in the lumbar region and extremity exposed to the ruminal cannula, already presenting necrosis. The region was cleaned, removing larvae (myiasis) for better exposition of the fracture; in the following day, an osteotomy was done to remove exposed bone fragments. A trichotomy, cleaning, and debridement of the lesion and their adjacencies were done, with subsequent sedation and locoregional paralumbar anesthesia with lidocaine for resection of necrotic bone fragments. Cutaneous and muscle syntheses were not done because the region presented permanent contact with the rumen content. The post-operatory management was based on daily cleanings and bandages, with administration of antibiotics every $48 \mathrm{~h}$ for 20 days. The total recovery of the animal occurred within 45 days after the surgery.

Discussion: Despite rib fractures in buffalos are mainly related to mineral deficiency, the case of the present study showed that these fractures are not always related to pre-existent causes. The clinical signs of the lesion were focal, because they refer to an open fracture that did not caused injuries to other structures, thus not determining an associated symptomatology. Opened rib fractures are rare, and most of them are healed by second intention without veterinary intervention. Regarding open fractures, the decontamination and debridement of a lesion and their adjacencies with removal of necrotic tissues and use of antibiotics are essential for prevention of infections. When the lesion is in a contaminated region by permanent contact with rumen content, as in this case, daily cleaning with bandages is needed for a best healing, but synthesis of tissues is not indicated because there is a possibility of contamination and formation of abscesses. Therefore, procedures that ensure the decontamination of the wound and prevention of infections with prolonged use of antibiotics are essential for a better healing of open rib fractures in regions that are subjected to constant contamination.
\end{abstract}

Keywords: fracture of rib, bubaline, rumenostomy.

DOI: $10.22456 / 1679-9216.101055$ 


\section{INTRODUCTION}

Despite the rusticity of buffaloes and their high capacity of adaptation to different environment conditions, they present susceptibility to several diseases, and the lack of adequate managements increases the risks of occurrence of diseases in these animals [2].

Among many diseases that affect buffalo herds, rib fractures deserve attention. It is mostly related to mineral deficiency, mainly phosphorus, and is very common in animals without or with inadequate supply of minerals in diet [11,12]. However, other causes, such as traumas, can be related to rib fractures [4,12].

Rib fractures in ruminants are rarely diagnosed and usually present conservative treatment; however, cases with presence of contaminated wounds require extra attention $[6,14]$. The objective of the present work was to report an open fracture of the last rib of a buffalo with ruminal cannula, describing the case from the diagnosis to the surgical treatment.

\section{CASE}

The animal studied was an adult female water buffalo (Bubalus bubalis) with live weight of approximately $500 \mathrm{~kg}$ and body condition index of 3.5 (1 to 5 scale, according to Alapati et al. [1]), which had been well fed and receiving minerals. The animal had a ruminal cannula for almost a year, and presented an exudative cutaneous lesion with increasing volume and myiasis (Figure 1A). The animal presented normal appetite and respiration and good physical condition and nutritional state, with pain reaction to the touch in the region of the lesion and their adjacencies; it presented no claudication and reluctance to remain in left lateral decubitus, and no discomfort. The general parameters and behavior of the animal were apparently normal, and the physical exam showed a heartbeat of $60 \mathrm{bpm}$, respiratory frequency of 49 cycles $\mathrm{min}^{-1}$, and rectal temperature of $37.9^{\circ} \mathrm{C}$, without significant changes for the case. The clinical inspection of the cutaneous lesion showed an oblique-type fracture in the body of the last left rib, presenting a bone exposure in the lumbar region with extremity exposed to the ruminal cannula, evidencing necrosis of the exposed portion (Figure 1B).

A cleaning of the surgical wound and removal of larvae was done (Figure 1B). In the following day, a surgical resection of bone fragments was done for their removal, with adequate bone healing, since there was necrosis in the exposed portion (Figure 1B). Therefore, the animal was sedated using Xilazina $2 \%{ }^{1}\left(5 \mathrm{mg} \mathrm{kg}^{-1}\right)$, physically contained by the Italian method, and, subsequently, a locoregional paralumbar anesthesia with lidocaine was done, without constrictor vase ${ }^{2}$.

The ruminal cannula was removed, and an aseptic preparation was done with trichotomy and chlorhexidine gluconate at $0.5 \%$ around the rumenostomy, mainly in adjacent areas to the lesion. Cutaneous and muscle divisions were done a scalpel around the lesion to better expose the fractured rib and necrotic tissues. Then, an osteotomy was done, using a wire saw, with removal of exposed bone tips and necrotic tissues (Figure 2B). Cutaneous and muscle syntheses were not done because the region presented permanent contact with the rumen content.

The post-operatory procedures consisted of daily cleanings and bandages, using oxitetraciclina ${ }^{1}$ $\left(20 \mathrm{mg} \mathrm{kg}^{-1}\right.$ ) every $48 \mathrm{~h}$ for 20 days [Figure $2 \mathrm{C}$ ]. The complete recovering of the animal, with total healing, occurred within 45 days after the surgery.

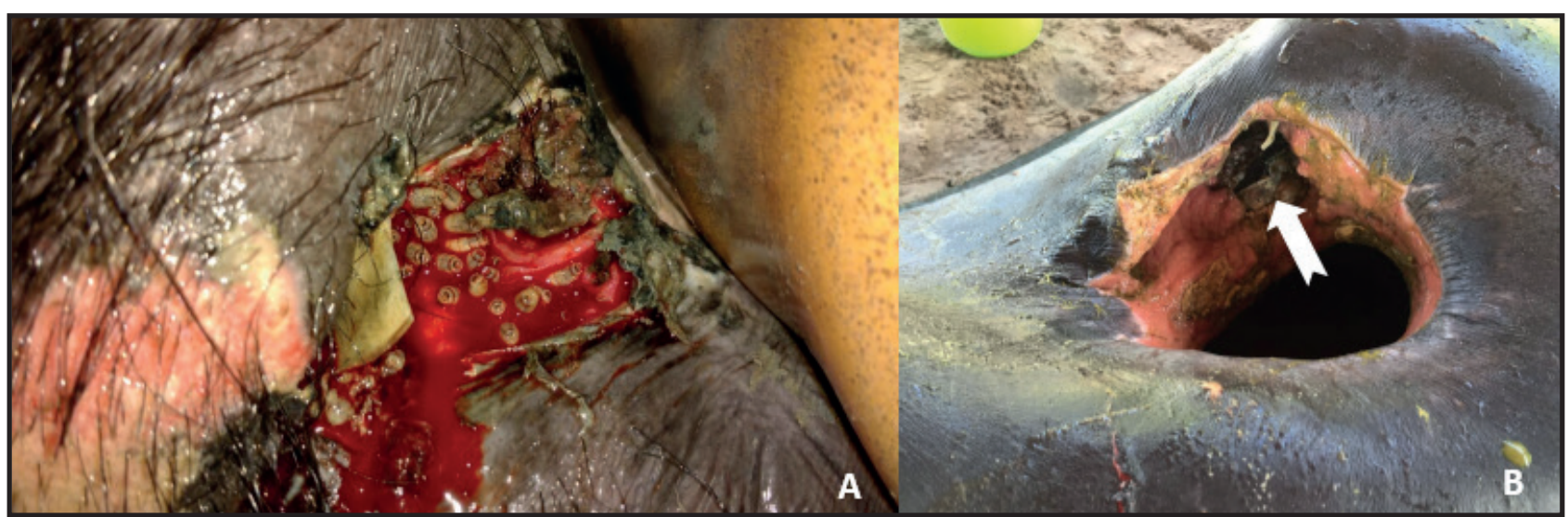

Figure 1. Photographic image of the lesion with bloody exudate and myiasis below the ruminal cannula. A- Presence of myiasis. B- Lesion after cleaning and debridement, containing necrotic bone exposure. 


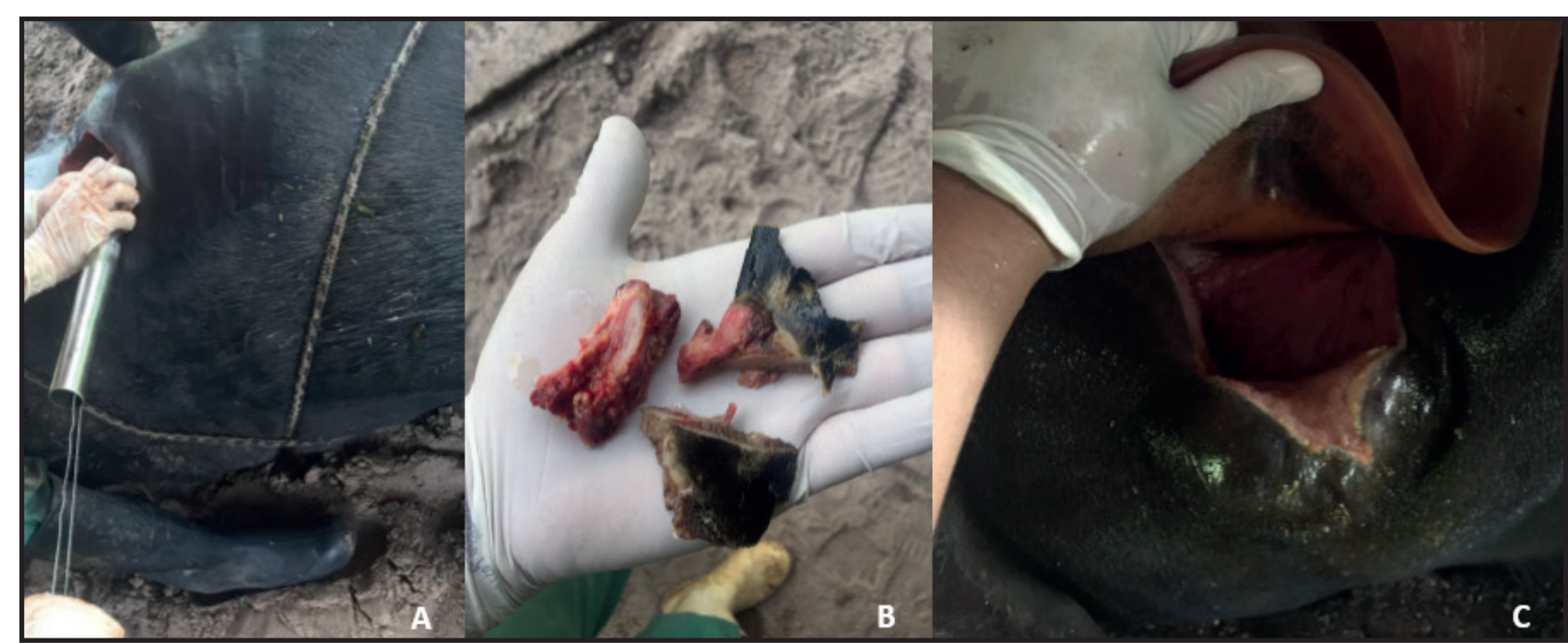

Figure 2. Photographic image of surgical treatment, osteotomy, bone fragments, and healing evolution. A- Osteotomy of exposed bone fragments, using a wire saw. B- Extracted bone fragments. C- Lesion after osteotomy, extraction of necrotic bone fragments, and healing.

\section{DISCUSSION}

Rib fractures in ruminants, especially bovine and bubaline, are extremely rare causes for veterinary appointments [4]. In buffalos, this is usually associated with phosphorus and copper deficiencies, which have higher incidence in young animals with clinical evidence of previous osteopathy $[11,12]$. In the case of the present study, the fracture occurred in an adult female buffalo with good body conditions that was receiving mineral supply in diet, denoting traumatic causes with no nutritional and age predispositions or no preexistent pathologies.

Many cases of clinically diagnosed rib fractures in ruminants shows claudication and alterations in respiratory movements as symptoms; but acute-type rib fractures often present unspecific and not palpable clinical signs, with spontaneous resolution $[3,4]$. The particularity of the case evaluated was that the animal had a ruminal cannula. The lesions and clinical signs were restricted to the lesion region and their adjacencies, with local swelling, sensitivity to pain, presence of exudates, and focal tissue necrosis. The clinical signs in this type of fracture depend on the conditions to which the fracture is subjected; in this case, the fracture was open, thus, there were no damages to intracavitary tissues and adjacent internal organs.

Clinical signs in rib fractures are unspecific because they are mainly related to secondary lesions in organs or adjacent tissues to the fracture location, which are caused by fragments of the fractured bone. Inspiratory dyspnea is a topical sign of rib fracture, but clinical signs related to generalized peritonitis, acute bronchopneumonia, and cavitary stroke can also be found $[5,4]$.

The ribs most affected by fractures are between the $9^{\text {th }}$ and $11^{\text {th }}$ rib, because they form a greater curvature and absorb primary impacts [3]. However, the case of the present study showed an oblique fracture in the body of the last rib, with exposition of the extremity to the border of the ruminal cannula. According to results found by Pereira \& Cardoso [12] and Braun et al. [4], open rib fractures in bovine and bubaline are rare, and the diagnostic is difficult, leading to a heling by second intention without veterinary intervention. However, the animal of the present case required especial attention, since the rumen content caused local contamination and facilitated the bone exposure by the fistula border, inhibiting the healing.

Procedures for the management of open fractures were considered for the treatment used in this case of rib fracture, considering their advances based on decontamination and debridement of the lesion and their adjacencies and on prevention of secondary bacterial infection $[8,10]$. Osteotomy and removal of non-viable tissues, and cleaning of exudates and residues were done to minimize the risk of infection and promote the effective healing of the wound; no tissue synthesis was done, since the region presented risk of contamination and possible formation of abscesses because of the constant contact with rumen content.

The risk of contamination of the wound by rumen content continued after the surgery until the total healing; however, auxiliary preventive measures were done, such as daily cleaning and debridement with 
$0.9 \%$ physiological solution and use of antibiotics. The cleaning of a wound with $0.9 \%$ physiological solution under controlled pressure and use of antibiotics contribute significantly to the healing of the wound $[8,9]$; these procedures maintain a natural $\mathrm{pH}$ of the skin, control bacterial infection, and assists in decreasing the odor, without tissue damages.

However, the case was not a simple wound; the constant contamination by ruminal fluid required a daily care with bandages, which was essential for the recovery of the animal. Despite the relatively long period, the animal had a complete recovery, but procedures such as photodynamic therapy would be interesting for this type of wound [14].

Therefore, removal of necrotic tissues and bone fragments and use of procedures to minimize contamination of wounds and prevent systemic infections, such as cleaning of the lesion and their adjacencies and prolonged use of antibiotics, are essential for treatment of open fractures in regions subjected to constant contaminations.

\section{MANUFACTURERS \\ ${ }^{1}$ Vallée S/A Produtos Veterinários. Montes Claros, MG, Brazil. \\ ${ }^{2}$ Laboratório Bravet Ltda. Rio de Janeiro, RJ, Brazil. \\ ${ }^{3}$ Chemitec Agro-Veterinária Ltda. Ipiranga, SP, Brazil.}

Acknowledgements. The authors thank the Center of Biotechnology in Animal Reproduction (CEBRAN) and the staff of the Veterinary Hospital for Large Animals (UFPA) for their assistance in the case evaluated.

Declaration of interest. The authors declare no conflicts of interest. The authors are the only responsible for the content and writing of this article.

\section{REFERENCES}

1 Alapati A., Kapa S.R., Jeepalyam S., Rangappa P. \& Yemireddy K.R. Development of the body condition score system in Murrah buffaloes: validation through ultrasonic assessment of body fat reserves. Journal Veterinary Science. 11(1): 1-8. DOI: $10.4142 /$ jvs.2010.11.1.1

2 Santos C.L.R., Santos Júnior J.B., Cunha M.C., Nunes S.R.F., Bezerra D.C., Torres Júnior J.R.S. \& Chaves N.P. 2016. Nível tecnológico e organizacional da cadeia produtiva da bubalinocultura de corte no estado do Maranhão. Arquivos do Instituto Biológico. 86: 19. DOI: 10.1590/1808-1657000022014

3 Blowey R. \& Bell N. 2014. Rib fractures in slaughter cattle. Veterinary Record. 175:231. DOI: 10.1136/vr.g5500

4 Braun U., Warislohner S., Hetzel U. \& Nuss K. 2017. Case report: clinical and postmortem findings in four cows with rib fracture. BMC Research Notes. 10: 85. DOI: 10.1186/s13104-017-2415-1

5 Braun U., Ohlerth S., Sydler T., Wehrli M. \& Gerspach C. 2009. Trachealkollaps mit Dyspnoe bei 2 Kälbern mit multipler Rippenfraktur. Schweizer Archiv fur Tierheilkunde. 151: 83-85. DOI: 10.1024/0036-7281.151.2.83

6 Câmara A.C.L., Calado E.B., Antunes J.M.A.P., Oliveira C.M.M., Afonso J.A.B., \& Costa N.A. 2014. Tratamento conservativo e cirúrgico em 22 ruminantes com fraturas em membros. Pesquisa Veterinária Brasileira. 34(11): 10451050. DOI: $10.1590 / \mathrm{S} 0100-736 \mathrm{X} 2014001100001$

7 Damé M.C.F., Riet-Correa F. \& Child A.L. 2013. Doenças hereditárias e defeitos congênitos diagnosticados em búfalos (Bubalus bubalis) no Brasil. Pesquisa Veterinária Brasileira.33(7): 831-839. DOI: 10.1590/S0100-736X2013000700001

8 Giglio P.N., Cristante A.F., Pecora J.R., Helito C.P., Lima A.L.L.M. \& Silva J.S. 2015. Avanços no tratamento das fraturas expostas. Revista Brasileira de Ortopedia. 50(2): 125-130. DOI: 10.1016/j.rboe.2015.02.009

9 Mandelbaum S.H., Di Santis E.P. \& Mandelbaum M.H.S. 2003. Cicatrização: conceitos atuais e recursos auxiliares - Parte II. In: Anais Brasileiro de Dermatologia (Rio de Janeiro, RJ). 78(5): 525-542. DOI: 10.1590/S036505962003000500002

10 Muzzi L.A.L., Muzzi R.A.L. \& Gabellini E.L.A. 2009. Técnica de fistulação e canulação do rúmen em bovinos e ovinos. Ciência e agrotecnologia. 33: 2059-2064. DOI: 10.1590/S1413-70542009000700060

11 Oliveira C.M.C. 2014. Diagnósticos das deficiências de macro e micro minerais em búfalas (Bubalus bubalis) provenientes da Ilha de Marajó, Estado do Pará. 70f. Belém, PA. Tese (Doutorado em Ciência Animal) - Programa de Pós-Graduação em Ciência Animal, Universidade Federal do Pará.

12 Pereira W.L.A. \& Cardoso E.C. 2011. Avaliação da ocorrência de fraturas de arcos costais de bufalinos de abate, nas deficiências de fósforo e cobre. Revista Portuguesa de Ciências Veterinárias. 106 (577-580): 53-57.

14 Sellera F.P., Barbosa B.S., Gargano R.G., Benesi F.J. \& Pogliani F.C. 2014. Terapia fotodinâmica no tratamento de ferida causada por miíase em vulva de caprino - relato de caso. Acta Veterinaria Brasilica. 8(1): 74-77. DOI: 10.21708/avb.2014.8.1.3557 